\title{
PENERAPAN METODE KONSEP NILAI HASIL (EARNED VALUE CONCEPT) PADA PROYEK PENINGKATAN JALAN ASPAL DI LOKASI F4 (SUNGAI SIRIH)
}

\author{
Surya Adinata ${ }^{1}$, Akbar Alfa ${ }^{2}$ \\ ${ }^{1}$ Program Studi Teknik Sipil Fakultas Teknik Universitas Islam Kuantan Singingi \\ ${ }^{2}$ Program Studi Teknik Sipil Fakultas Teknik dan Ilmu Komputer Universitas Islam Indragiri. \\ Email: cintiacarolinee@yahoo.com (korespondensi)
}

\begin{abstract}
The cost control is a very important aspect in project management. Poor cost control often results in project construction costs that differ from planned costs.

The applying of the Earned Value Concept method for analytical calculations requires the following data: Implementation time along with the S curve; Volume data of each work item; Percentage of work weighted; Standard daily reports, weekly reports, and monthly project reports; Actual project financial data and SPI. The stage of data analysis for each job are: determining of BCWS (Budgete Cost Of Work Schedule); BCWP (Budgeted Cost of Work Performed; ACWP (Actual Cost of Work performed) Analysis of variance and performance index from the Earned Value Concept method. It consists of: Cost Variance (CV) and Schedule Variance (SV), Cost Performance Index (CPI) and Schedule Performance Index (SPI).

The results of the analysis of the applied of the Earned Value Concept method of PT. Riau Maju Cemerlang obtained a gross cost gain of around Rp. 173,591,516.52 or 5.00\% of the total construction price without VAT value. The initial planning time for project work began on 26 July and the initial planning time ended on 17 December (145 HK) turned out to be 27 December (155 HK). The applied of the Result Value Concept method to the project can find out the remaining value of the project costs for the remaining work and how much the total cost has been used for the project.
\end{abstract}

Keywords: Earned Value Concept, ACWP, BCWS, BCWP

\begin{abstract}
Abstrak
Pengendalian biaya adalah suatu aspek yang sangat penting dalam manajemen proyek. Pengendalian biaya yang kurang baik, tidak jarang menyebabkan biaya konstruksi proyek yang berbeda dengan biaya yang direncanakan.

Penerapan metode Konsep Nilai Hasil (Earned Value Concept) untuk perhitungan analisanya diperlukan data-data: Waktu pelaksanaan beserta Kurva S; Data volume masing-masing item pekerjaan; Bobot persentase pekerjaan; Laporan harian standar, Laporan mingguan, dan Laporan bulanan proyek; Data keuangan proyek aktual dan SPI. Sedangkan tahapan analisa data pada masing-masing pekerjaan, yaitu: menentukan BCWS (Budgete Cost Of Work Schedule); Menentukan BCWP (Budgeted Cost of Work Performed; Menentukan ACWP (Actual Cost of Work performed). Analisa Varian dan Indeks Kinerja dari metode Konsep Nilai Hasil (Earned Value Concept). Penelitian ini terdiri dari : Varian Biaya atau Cost Varians (CV) dan Varian Jadwal atau Schedulle Varians (SV), Indeks Kinerja Biaya atau Cost Performed Indeks (CPI) dan Indeks Kinerja Jadwal (SPI).

Pada hasil akhir dari analisa penerapan metode Konsep Nilai Hasil (Earned Value Concept) PT. Riau Maju Cemerlang mengalami keuntungan biaya nilai brutonya kurang lebih Rp.173.591.516,52 atau 5,00 \% dari total harga konstruksi tanpa nilai PPn. Perencanaan awal waktu pelaksanaan pekerjaan proyek dimulai 26 Juli dan waktu perencanaan semula berakhir 17 Desember (145 HK) ternyata menjadi 27 Desember (155 HK). Penerapan metode Konsep Nilai Hasil terhadap proyek dapat mengetahui berapa nilai biaya proyek tersisa untuk pekerjaan yang masih tersisa dan berapa biaya total yang telah habis digunakan untuk proyek tersebut.
\end{abstract}

Kata kunci: Konsep Nilai Hasil, ACWP, BCWS, BCWP 


\section{PENDAHULUAN}

Provinsi Riau mempunyai luas wilayah 107.932,71 Km2 (Daratan 84.461,91 $\mathrm{Km} 2) / 80,1 \%$ dan Perairan 23.470,80 $\mathrm{Km} 2 / 19,9 \%$. Terdapat empat sungai besar yaitu Sungai Indragiri, Kampar, Siak, Rokan dan beberapa sungai kecil lainnya. Jalan nasional, provinsi, kabupaten/kota dan jalan desa/khusus melintasi sungai tersebut memerlukan jembatan dan juga jalan perkerasan. Sebagaimana Kabupaten Kuantan Singingi adalah hasil pemekaran dari kabupaten induk Kabupaten Indragiri Hulu yang dibentuk berdasarkan UU No. 53 tahun 1999, yang mana saat ini telah memiliki 15 kecamatan. Lokasi penelitian ini berada di desa F4 (Sungai Sirih) kecamatan Singingi Kabupaten Kuantan Singingi.

Pengendalian biaya adalah suatu aspek yang sangat penting dalam manajemen proyek. Pengendalian biaya yang kurang baik, tidak jarang menyebabkan biaya konstruksi proyek yang berbeda dengan biaya yang direncanakan. Penelitian ini menjelaskan suatu studi kasus pengendalian biaya kostruksi dengan menggunakan Konsep Hasil Nilai, suatu metode yang mengintegrasikan hubungan antara biaya dan waktu serta memberikan gambaran tentang kondisi kelangsungan proyek. Sehingga penelitian ini dengan judul "Penerapan Metode Konsep Nilai Hasil (Earned Value Concept) Pada Proyek Peningkatan Jalan Aspal di Lokasi F4 (Sungai Sirih).

Perumusan masalahnya adalah bagaimana hasil Penerapan Metode Konsep Nilai Hasil (Earned Value Concept) terhadap waktu dan biaya pada proyek ini?

Tujuan penelitian untuk mengetahui hasil Penerapan Metode Konsep Nilai Hasil (Earned Value Concept) terhadap waktu dan biaya pada proyek.

Batasan masalah untuk penelitian Pada Konsep Nilai Hasil adalah membuat analisa terhadap proyek dengan menggunakan indikator BCWS, ACWP dan BCWP; melakukan Analisis Varians Terpadu CV dan SV; mengetahui efisiensi penggunaan sumber daya dan indeks kinerja. CPI (Cost Performance Index), dan SPI (Scheduled Performance Index); analisa prakiraan biaya untuk pekerjaan tersisa ETC (Estimate To Completion) dan menghitung EAC proyek.

\section{LANDASAN TEORI}

Metode konsep nilai hasil (Earned Value Concept) adalah metode membuat prakiraan atau proyeksi keadaan masa depan proyek sehingga mereka memiliki cukup waktu untuk memikirkan cara-cara menghadapi segala persoalan di masa yang akan dating, atau lebih tepatnya suatu sistem pemantauan dan pengendalaian proyek. (Iman Soeharto, 1995).
Menilai status terkini proyek menggunakan sistem Earned Value memerlukan tiga komponen data penting yaitu:

1. Budgeted Cost Of The Work Scheduled (BCWS)

2. Budgeted Cost Of The Work Performed (BCWP)

3. Actual Cost of The Work Performed (ACWP)

Nilai Budgeted Cost Of Work Performed $(B C W P)=(\%$ pekerjaan yang telah dihasilkan) $\times$ (total anggaran). Nilai Budgeted Cost of Work Scheduled (BCWS) yaitu anggaran untuk suatu paket pekerjaan, tetapi disusun dan dikaitkan dengan jadwal pelaksanaan. Sedangkan Nilai Actual Cost of Work Performed (ACWP) adalah jumlah biaya aktual dari pekerjaan yang telah dilaksanakan.

Metode ini menggunakan indikator varians sebagaimana Tabel 1:

1. Varians biaya terpadu atau Cost Varians $(C V): C V=B C W P-A C W P$

2. Varians jadwal terpadu atau Schedule Varians (SV): SV = BCWP - BCWS

Tabel 1 Analisis varians terpadu

\begin{tabular}{|c|c|c|}
\hline $\begin{array}{l}\text { Varians } \\
\text { Jadwal } \\
\text { SV = } \\
\text { BCWP- } \\
\text { BCWS }\end{array}$ & $\begin{array}{l}\text { Varians Biaya } \\
\begin{array}{l}\text { CV = BCWP- } \\
\text { ACWP }\end{array}\end{array}$ & Keterangan \\
\hline Positif & Positif & $\begin{array}{l}\text { Pekerjaan lebih cepat } \\
\text { dari yang } \\
\text { direncanakan, dengan } \\
\text { biaya lebih kecil dari } \\
\text { pada anggaran. }\end{array}$ \\
\hline Positif & Negatif & $\begin{array}{l}\text { Pekerjaan lebih cepat } \\
\text { dari yang } \\
\text { direncanakan, alokasi } \\
\text { biaya lebih besar dari } \\
\text { anggaran. }\end{array}$ \\
\hline Positif & Nol & $\begin{array}{l}\text { Pelaksanaan lebih } \\
\text { cepat dari jadwal } \\
\text { dengan alokasi biaya } \\
\text { sama dengan } \\
\text { anggaran. }\end{array}$ \\
\hline Nol & Nol & $\begin{array}{l}\text { Pelaksanaan sama } \\
\text { dengan dijadwalkan } \\
\text { dengan alokasi biaya } \\
\text { sama dengan } \\
\text { anggaran. }\end{array}$ \\
\hline Nol & Negatif & $\begin{array}{l}\text { Pelaksanaan sama } \\
\text { dengan dijadwalkan } \\
\text { dengan biaya lebih } \\
\text { besar dari anggaran. }\end{array}$ \\
\hline Negatif & Positif & $\begin{array}{l}\text { Pelaksanaan lebih } \\
\text { lambat dari jadwal } \\
\text { dengan biaya lebih } \\
\text { kecil dari anggaran. }\end{array}$ \\
\hline
\end{tabular}

(Sumber : Manajemen Proyek, Iman Soeharto, 1995)

Efisiensi penggunaan sumber daya dinyatakan sebagai indeks produktivitas atau indeks kinerja dihitung dengan : 
1. Indeks Kinerja Biaya (Cost Performance Indeks): CPI= BCWP/ACWP

2. Indeks Kinerja Jadwal (Schedule Performance Indeks): SPI = BCWP/BCWS Maka jika:

a. Angka indeks kinerja kurang dari satu $(<1$ ) berarti pengeluaran lebih besar dari anggaran atau waktu pelaksanaan lebih lama dari jadwal rencana.

b. bila angka indeks kinerja lebih dari satu $(>1)$ maka kinerja penyelenggaraan proyek lebih baik dari perencanaan, dalam arti pengeluaran lebih kecil dari anggaran atau jadwal lebih cepat dari rencana.

c. jika didapat angka yang terlalu tinggi $(>>1)$, berarti prestasi pelaksanaan pekerjaan sangat baik, perlu diadakan pengkajian apakah mungkin perencanaannya atau anggarannya justru yang tidak realistis.

d. Perkiraan biaya untuk pekerjaan tersisa (ETC), dirumuskan berikut: $\mathrm{ETC}=$ (Anggaran total $-\mathrm{BCWP})$ : CPI

e. Perkiraan biaya total proyek atau Estimation All Cost (EAC) dirumuskan:

$E A C=A C W P+E T C$

f. Perkiraan waktu untuk pekerjaan tersisa atau Estimation Temporary Schedule (ETS), dirumuskan:

ETS $=($ Ttotal - Twp $):$ SPI

Ttotal $=$ Rencana waktu pelaksanaan

Twp = Waktu yang seharusnya dicapai sesuai kemajuan

g. Perkiraan waktu total proyek atau (Estimation All Schedule) dirumuskan:

EAS $=$ Waktu evaluasi + ETS

\section{METODOLOGI PENELITIAN}

Data Proyek Peningkatan Jalan Aspal Sepanjang $2.00 \mathrm{Km}$ ini dengan Direksi dan Suvervisi adalah Dinas Pekerjaan Umum dan Penataan Ruang Kabupaten Kuantan Singingi dan Kontraktor pelaksana PT. Riau Maju Cemerlang, dengan waktu pelaksanaan selama 145 hari kalender serta nilai kontrak sebesar Rp.3.819.013.363,49 yang diambil dari APBD Kabupaten Kuantan Singingi dan tanggal pelaksanaan kontrak proyek 26 Juli sampai 17 Desember 2015.

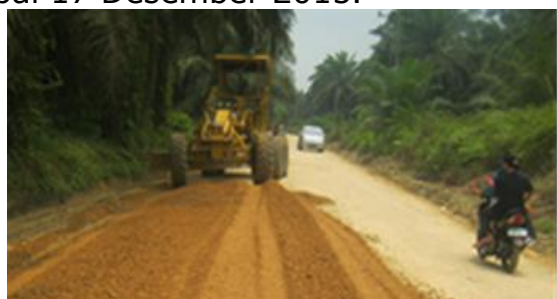

Gambar 1 Lokasi Penelitian Proyek
Perhitungan analisanya diperlukan datadata sebagai berikut :

a. Waktu pelaksanaan beserta Kurva S.

b. Data volume masing-masing item pekerjaan

c. Bobot persentase pekerjaan.

d. Laporan harian standar, laporan mingguan, dan laporan bulanan proyek. Data keuangan proyek aktual dan SPP.

Tahapan analisa data pada masingmasing pekerjaan, yaitu :

a. Menentukan BCWS (Budgete Cost Of Work Schedule)

BCWS $=\%$ Rencana $\times$ BAC

Dimana :

BCWS = Anggaran biaya yang telah direncanakan berdasarkan jadwal pelaksanaan proyek

$\%$ Rencana $=$ Rencana kemajuan fisik

BAC = Total anggaran

b. Menentukan BCWP (Budgeted Cost of Work Performed)

$\mathrm{BCWP}=\%$ Aktual $\times \mathrm{BAC}$

Dimana :

BCWP = Anggaran biaya disediakan untuk melaksanakan pekerjaan

$\%$ Aktual = Realisasi kemjuan fisik

BAC = Total anggaran

c. Menentukan ACWP (Aktual Cost of Work performed)

ACWP $=$ Pengeluaran aktual untuk pembelanjaan biaya proyek

Pengeluaran-pengeluaran tersebut meliputi pembelanjaan untuk pembelian material, mobilisasi alat berat, kendaraaan proyek, belanja makan dan minum, gaji-gaji pekerja, pengeluaran kantor dan foto copi, biaya kerusakan peralatan proyek, dana overhead tak terduga lainnya yang diambil dari sumber pendanaan pada proyek ini.

d. Analisa Varian dan Indeks Kinerja dari metode Konsep Nilai Hasil yang terdiri dari: (Iman Soeharto, 1995)

Varian Biaya atau Cost Varians (CV), dihitung dengan rumus :

$$
C V=B C W P \text { - ACWP }
$$

Varian Jadwal atau Schedulle Varians (SV), dihitung dengan rumus:

$$
\mathrm{SV}=\mathrm{BCWP} \text { - BCWS }
$$

Indeks Kinerja Biaya atau Cost Performed Indeks (CPI), dengan rumus :

$$
\text { CPI = BCWP / ACWP }
$$

Indeks Kinerja Jadwal (SPI), yang dihitung dengan rumus :

$$
\mathrm{SPI}=\mathrm{BCWP} / \mathrm{BCWS}
$$

\section{ANALISA DAN PEMBAHASAN}

Pengendalian waktu dan biaya pada proyek ini adalah dengan menggunakan suatu metode yaitu Konsep Nilai Hasil (Earned Value Concept) sebagai berikut :

1. Perhitungan Budgeted Cost of Work Schedulle ( BCWS ) 
Rumus untuk analisa data BCWS $=\%$ Rencana x Total anggaran

Bulan Juli ;

BCWS $=0,237 \% \times \mathrm{Rp}$. 3.471.830.330,45

$=$ Rp. 8.228.237,883

Bulan Agustus

BCWS $=4,067 \% \times \mathrm{Rp}$. 3.471.830.330,45

$=$ Rp. $141 \cdot 214 \cdot 339,431$

Bulan September;

BCWS $=22,553 \% \times \mathrm{Rp}$. 3.471.830.330,45

$=$ Rp. 783.018.122,584

Bulan Oktober:

BCWS $=50,067 \% \times \mathrm{Rp}$. 3.471.830.330,45

$=$ Rp. 1.738.266.391,060

Bulan Nopember:

BCWS $=96,229 \% \times$ Rp. 3.471.830.330,45

$=$ Rp. 3.340.912.794,060

Bulan Desember ;

BCWS $=100,00 \% \times \mathrm{Rp}$. $3.471 .830 .330,450$

$=$ Rp. 3.471.830.330,45

Bila hasil dari analisis BCWS dibuatkan dalam grafik "S" seperti gambar 2 berikut ini:

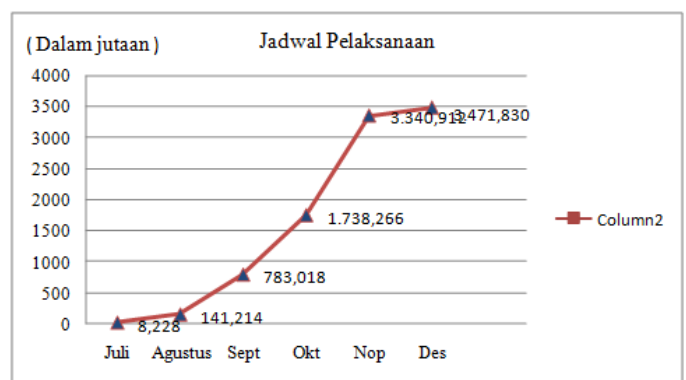

Gambar 2 Varians data dengan grafik "S" untuk nilai BCWS

2. Perhitungan Budgeted Cost of Work Performend (BCWP).

BCWP = \% Pekerjaan yang telah dihasilkan x Total anggaran

Bulan Juli :

BCWP $=0,000 \% \times \mathrm{Rp}$ 3.471.830.330,45

$=$ Rp. 0,00

Bulan Agustus

$\mathrm{BCWP}=1,738 \% \times \mathrm{Rp}$. $3.471 .830 .330,45$

$=$ Rp. $60.340 .411,143$

Bulan September;

$B C W P=31,487 \% \times \mathrm{Rp}$. 3.471.830.330,45

$=$ Rp. $1.093 \cdot 175.216,145$

Bulan Oktober .

BCWP $=48,971 \% \times$ Rp. 3.471.830.330,45

$=$ Rp. 1.700.190.031,125

Bulan Nopember:

$\mathrm{BCWP}=90,632 \% \times \mathrm{Rp}$. 3.471.830.330,45

$=$ Rp. 3.146.589.265,093
Bulan Desember ;

$\mathrm{BCWP}=100,00 \% \times \mathrm{Rp}$.

3.471.830.330,45

$=$ Rp. 3.471.830.330,45

Sehingga hasil analisa BCWP dibuatkan grafiknya adalah sebagai berikut :

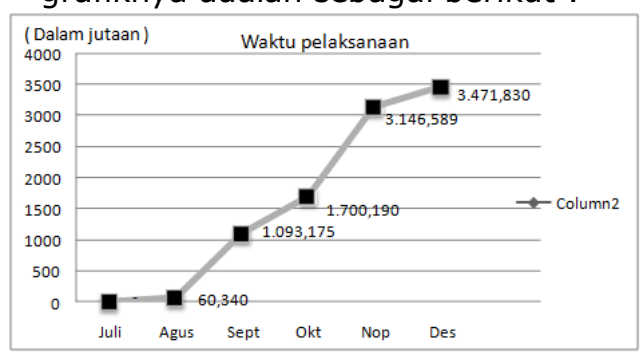

Gambar 3 Varians data dengan grafik "S" untuk nilai BCWP

3. Nilai Biaya yang telah dikeluarkan atau Actual Cost of Work Performend (ACWP) diperoleh dari data bruto keuangan proyek adalah sebagai berikut:

Bulan Juli

ACWP $=$ Rp. 5.201.745,50

Komulatif = Rp. 5.201.745,50

Bulan Agustus

ACWP $=$ Rp. 52.387.176,94

Komulatif $=$ Rp. $5 \cdot 201 \cdot 745,50+$ Rp. 52.387.176,94 = Rp. 57.594.922,436

Bulan September

ACWP $=$ Rp. 990.760.109,85

Komulatif $=$ Rp. $57.594 .922,436+R p$ 990.760.109,85 $=$ Rp. 1.048.355.032,283

Bulan Oktober

ACWP $=$ Rp. 571.075.972,36

Komulatif $=$ Rp. $1.048 .355 .032,283+$ Rp. 571.075.972,36 $=$ Rp. $1.619 .431 .004,647$

Bulan Nopember

ACWP $=$ Rp. 1.390.281.627,41

Komulatif $=$ Rp. 1.619.431.004,647+ Rp. $1.390 .281 .627,41$ = Rp. 3.009.712.632,061

Bulan Desember

ACWP $=$ Rp. 288.526.181,87

Komulatif $=$ Rp. $3 \cdot 009 \cdot 712 \cdot 632,061+$ Rp. 288.526.181,87 $=$ Rp. 3.298.238.813,928

Jumlah komulatif dari nilai ACWP di atas dari bulan Juli hingga Desember adalah Rp. 3.298.238.813,928. Bila dibuatkan dalam grafik nilai ACWP adalah sebagai berikut pada gambar 4.

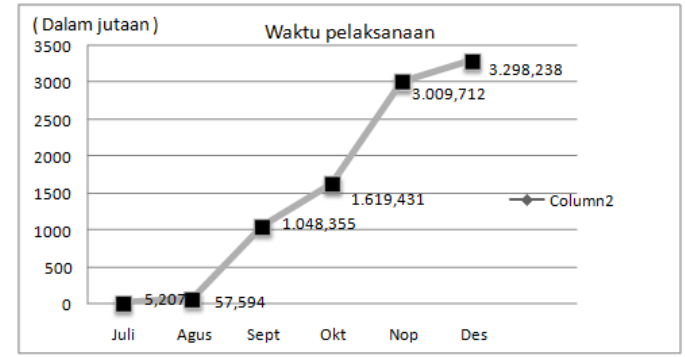


Gambar D.3 varians data dengan grafik "s" untuk nilai ACWP

Bila nilai ACWP dibandingkan dengan BCWP akan terlihat perbandinganantara biaya yang telah dikeluarkan dengan biaya yang seharusnya dikeluarkan pada setiap laporan akhir bulanan proyek. Berikut ini tabel gabungan hasil analisa perhitungan ACWP, BCWS dan BCWP.

Kemudian setelah dihitung nilai Budgeted Cost of Work Schedulle (BCWS), Budgeted Cost of Work Performend (BCWP) dan Actual Cost of Work Performend (ACWP) dari bulan Juli sampai Desember dengan memakai rumus di atas akan didapatkan hasil yang tertera pada tabel 2 kemudian dibuatkan grafik " $S$ " untuk varians analisisnya.

Pada grafik D.1 dapat dilihat bahwa hanya pada bulan September pelaksanaanya lebih cepat dari yang direncanakan, diketahui dari hasil analisanya nilai BCWP lebih besar dari BCWS sedangkan pekerjaan selalu terlambat pada bulan Juli, Agustus, Oktober, November, dan Desember.

Hasil analisa perhitungan dengan metode Konsep Nilai Hasil pada proyek ini terlaksana dengan biaya yang kurang dari anggaran, diketahui dari nilai BCWP selalu lebih besar dari nilai ACWP. Namun, dari segi waktu pelaksanaan pekerjaan ini mengalami keterlambatan selama 10 hari kalender.

Tabel 2 Nilai komulatif ACWP, BCWS dan BCWP

\begin{tabular}{l|l|r|r|r}
\hline No & \multicolumn{1}{|c|}{$\begin{array}{c}\text { Bulan } \\
2012\end{array}$} & $\begin{array}{c}\text { ACWP } \\
\text { (Komulatif) } \\
\text { (Rp.) }\end{array}$ & $\begin{array}{c}\text { BCWS } \\
\text { (Komulatif) } \\
\text { (Rp) }\end{array}$ & \multicolumn{1}{|c}{$\begin{array}{c}\text { BCWP } \\
\text { (komulatif) } \\
\text { (Rp) }\end{array}$} \\
\hline 1 & Juli & $5.201 .745,50$ & $8.228 .237,883$ & 0,00 \\
\hline 2 & Agustus & $57.594 .922,436$ & $141.214 .339,431$ & $60.340 .411,143$ \\
\hline 3 & September & $1.048 .355 .032,283$ & $783.018 .122,584$ & $1.093 .175 .216,145$ \\
\hline 4 & Oktober & $1.619 .431 .004,647$ & $1.738 .266 .391,060$ & $1.700 .190 .031,125$ \\
\hline 5 & November & $3.009 .712 .632,061$ & $3.340 .912 .794,060$ & $3.146 .589 .265,093$ \\
\hline 6 & Desember & $3.298 .238 .813,928$ & $3.471 .830 .330,450$ & $3.471 .830 .330,45$ \\
\hline
\end{tabular}

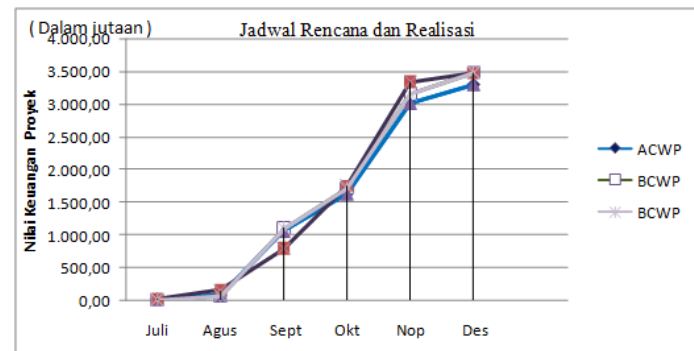

Gambar 4 Perbandingan nilai ACWP, BCWS dan BCWP

4. Perhitungan Schedule Performance Index (SPI), yaitu untuk mengetahui Indeks Kinerja Jadwal per bulannya adalah dengan rumus berikut :

Bulan Juli ;
SPI = Rp. 0,00: Rp.

Bulan Agustus ;

$$
8.228 .237,883=0,000
$$

SPI = Rp. 60.340.411,143: Rp.

Bulan September :

$$
141.214 .339,431=0.427
$$

SPI = Rp. 1.093.175.216,145:

Rp. $783.018 .122,584=1.396$

Bulan Oktober ;

SPI = Rp. 1.700.190.031,125:

Rp. $1.738 .266 .391,060=0.978$

Bulan Nopember

SPI = Rp. 3.146.589.265,093: Rp. 3.340.912.794,060 $=0.942$

Bulan Desember

SPI = Rp. 3.471.830.330,45:

Rp. $3.471 \cdot 830 \cdot 330,45=1,00$

Tabel 3 Nilai Schedulle Performance

Indeks (SPI)

\begin{tabular}{|c|l|r|r|r|} 
No & \multicolumn{1}{|c|}{$\begin{array}{c}\text { Bulan } \\
2012\end{array}$} & \multicolumn{1}{|c|}{ BCWP } & \multicolumn{1}{c|}{ BCWS } & SPI \\
\hline 1 & Juli & 0,00 & $8.228 .237,883$ & 0.00( \\
\hline 2 & Agustus & $60.340 .411,143$ & $141.214 .339,431$ & $0.42 ;$ \\
\hline 3 & September & $1.093 .175 .216,145$ & $783.018 .122,584$ & $1.39 \epsilon$ \\
\hline 4 & Oktober & $1.700 .190 .031,125$ & $1.738 .266 .391,060$ & $0.97 \varepsilon$ \\
\hline 5 & Nopember & $3.146 .589 .265,093$ & $3.340 .912 .794,060$ & 0.94 ; \\
\hline 6 & Desember & $3.471 .830 .330,45$ & $3.471 .830 .330,450$ & 1.00( \\
\hline
\end{tabular}

(Sumber : Hasil analisa)

Pada tabel 3 diketahui bahwa waktu pelaksanaan dan kinerja penyelenggaraan proyek pada bulan September lebih baik dari jadwal perencanaannya terlihat dari hasil nilai SPI $>1$. Pada bulan Juli dan Agustus terdapat nilai SPI $>1$ berarti prestasi pelaksanaan pekerjaan lebih baik. Sedangkan pelaksanaan waktu pekerjaan pada bulan Juli, Agustus, Oktober, November, dan Desembar terlihat dari hasil nilai SPI < 1 yang berarti prestasi Waktu pelaksanaan pekerjaan lebih lama daripada yang direncanakan. (Iman Soeharto, 1995).

5. Perhitungan Cost Performance Index ( CPI ), yaitu untuk mengetahui efisiensi penggunaan sumber daya. Ini dinyatakan dalan indeks produtivitas atau indeks kinerja. Untuk mengetahui besar kecilnya indeks kinerja, dapat dihitung dengan rumus CPI berikut :

Bulan Juli :

$$
\text { CPI = BCWP : ACWP }
$$

SPI $=$ Rp. 0,00: Rp

$$
5.201 \cdot 745,50=0,000
$$

Bulan Agustus ;

SPI $=$ Rp. 60.340.411,143: Rp. $57.594 .922,436=1.048$

Bulan September :

SPI = Rp. 1.093.175.216,145: Rp. $1.048 .355 .032,283=1.043$

Bulan Oktober ;

SPI = Rp. 1.700.190.031,125: Rp. $1.619 .431 .004,647=1.050$

Bulan Nopember

SPI = Rp. 3.146.589.265,093: Rp. 3.009.712.632,061 = 1.045

Bulan Desember 
SPI $=$ Rp. 3.471.830.330,45:

Rp. $3.298 .238 .813,928=1.053$

Kemudian nilai indeks kinerja atau CPI dimuat dalam tabel 4 berikut :

Tabel 4 Nilai Hasil Perhitungan CPI

\begin{tabular}{|c|l|r|r|r}
\hline No & \multicolumn{1}{|c|}{ Bulan } & \multicolumn{1}{|c|}{ BCWP } & \multicolumn{1}{c|}{ ACWP } & CPI \\
\hline 1 & Juli & 0,00 & $5.201 .745,50$ & $0.00 \mathrm{C}$ \\
\hline 2 & Agustus & $60.340 .411,143$ & $57.594 .922,436$ & $1.04 \varepsilon$ \\
\hline 3 & September & $1.093 .175 .216,145$ & $1.048 .355 .032,283$ & $1.04 \vdots$ \\
\hline 4 & Oktober & $1.700 .190 .031,125$ & $1.619 .431 .004,647$ & $1.05 \mathrm{C}$ \\
\hline 5 & Nopember & $3.146 .589 .265,093$ & $3.009 .712 .632,061$ & 1.045 \\
\hline 6 & Desember & $3.471 .830 .330,45$ & $3.298 .238 .813,928$ & $1.05 \Xi$
\end{tabular}

(Sumber : Hasil analisa)

Pada Time Schedule proyek bahwa BCWS dihitung berdasarkan target rencana sedangkan BCWP dihitung dari prestasi pekerjaan yang sebenarnya. Pada perhitungan indeks kinerja biaya (CPI) bulan Agustus sampai bulan Desember didapatkan CPI lebih dari 1, hal ini berarti pengeluaran lebih kecil. Artinya kinerja penyelenggaraan lebih baik dari perencanaan atau pengeluaran lebih kecil dari anggaran dan jadwal lebih cepat dari rencana.

Namun terjadi sebaliknya pada bulan Juli yang sebenarnya pelaksanaan proyek hanya ada 1 (satu) minggu dalam bulan ini, sebagaimana mulai berlakunya pelaksanaan proyek.

6. Perhitungan Schedule Varians ( SV ) yaitu Bulan Juli : $\mathrm{SV}=\mathrm{BCWP}-\mathrm{BCWS}$

SV $=$ Rp. $0,00-$ Rp. 8.228.237,883 $=(-)$ Rp. $8,228,237.88$

Bulan Agustus ;

SV $\quad$ Rp. 60.340.411,143 - Rp. $141.214 .339,431$

$=(-)$ Rp. $80,873,928.29$

Bulan September ;

SV $=$ Rp. 1.093.175.216,145 - Rp. 783.018.122,584 $=$ Rp. 310,157,093.56

Bulan Oktober :

SV $=$ Rp. $1.700 .190 .031,125-$ Rp. $1.738 .266 .391,060$ $=(-)$ Rp. 38,076,359.93

Bulan Nopember

SV $=$ Rp. 3.146.589.265,093 - Rp. 3.340.912.794,060 $=(-)$ Rp. 194,323,528.97

Bulan Desember

SV $=$ Rp. 3.471.830.330,45 - Rp. $3.471 .830 .330,45$

$=$ Rp. 0,00

Tabel 5 Nilai Hasil Perhitungan SV

\begin{tabular}{|c|l|r|r|r|}
\hline No & \multicolumn{1}{|c|}{ Bulan } & \multicolumn{1}{|c|}{ BCWP } & \multicolumn{1}{c|}{ BCWS } & SV \\
\hline 1 & Juli & 0,00 & $8.228 .237,883$ & $-8,228,:$ \\
\hline 2 & Agustus & $60.340 .411,143$ & $141.214 .339,431$ & $-80,873, !$ \\
\hline 3 & September & $1.093 .175 .216,145$ & $783.018 .122,584$ & $310,157,1$ \\
\hline 4 & Oktober & $1.700 .190 .031,125$ & $1.738 .266 .391,060$ & $-38,076,:$ \\
\hline 5 & Nopember & $3.146 .589 .265,093$ & $3.340 .912 .794,060$ & $-194,323,5:$ \\
\hline 6 & Desember & $3.471 .830 .330,45$ & $3.471 .830 .330,450$ & \\
\hline
\end{tabular}

(Sumber : Hasil analisa)

7. Perhitungan Cost Variance (CV) yaitu $C V=B C W P-A C W P$

Tabel 6 Nilai Hasil Perhitungan CV

\begin{tabular}{|r|l|r|r|r}
\hline No & \multicolumn{1}{|c|}{ Bulan } & \multicolumn{1}{|c|}{ BCWP } & \multicolumn{1}{c|}{ ACWP } & CV \\
\hline 1 & Juli & 0,00 & $5.201 .745,50$ & $-5,207,74$ \\
\hline 2 & Agustus & $60.340 .411,143$ & $57.594 .922,436$ & $2,745,48$ \\
\hline 3 & September & $1.093 .175 .216,145$ & $1.048 .355 .032,283$ & $44,820,18$ \\
\hline 4 & Oktober & $1.700 .190 .031,125$ & $1.619 .431 .004,647$ & $80,759,02$ \\
\hline 5 & Nopember & $3.146 .589 .265,093$ & $3.009 .712 .632,061$ & $136,876,63$ \\
\hline 6 & Desember & $3.471 .830 .330,45$ & $3.298 .238 .813,928$ & $173,591,51$ \\
\hline
\end{tabular}

(Sumber : Hasil analisa)

Bulan Juli ;

$\mathrm{CV}=$ Rp. 0,00 - Rp. 5.201.745,50 $=(-)$ Rp.5,207,745.50

Bulan Agustus ;

$\mathrm{CV}=$ Rp. $60 \cdot 340.411,143$ - Rp. 57.594.922,436 $=$ Rp. $2,745,488.71$

Bulan September;

$\mathrm{CV}=$ Rp. 1.093.175.216,145 - Rp. $1.048 .355 .032,283$

$=$ Rp. $44,820,183.86$

Bulan Oktober ;

$\mathrm{CV}=$ Rp. 1.700.190.031,125 - Rp. $1.619 .431 .004,647$

$=$ Rp. $80,759,026.48$

Bulan Nopember

$\mathrm{CV}=$ Rp. 3.146.589.265,093 - Rp. 3.009.712.632,061

$=$ Rp. $136,876,633.03$

Bulan Desember

$\mathrm{CV}=$ Rp. 3.471.830.330,45 - Rp.

3.298.238.813,928

$=$ Rp. $173,591,516.523$

Tabel 7 Nilai SV dan CV 


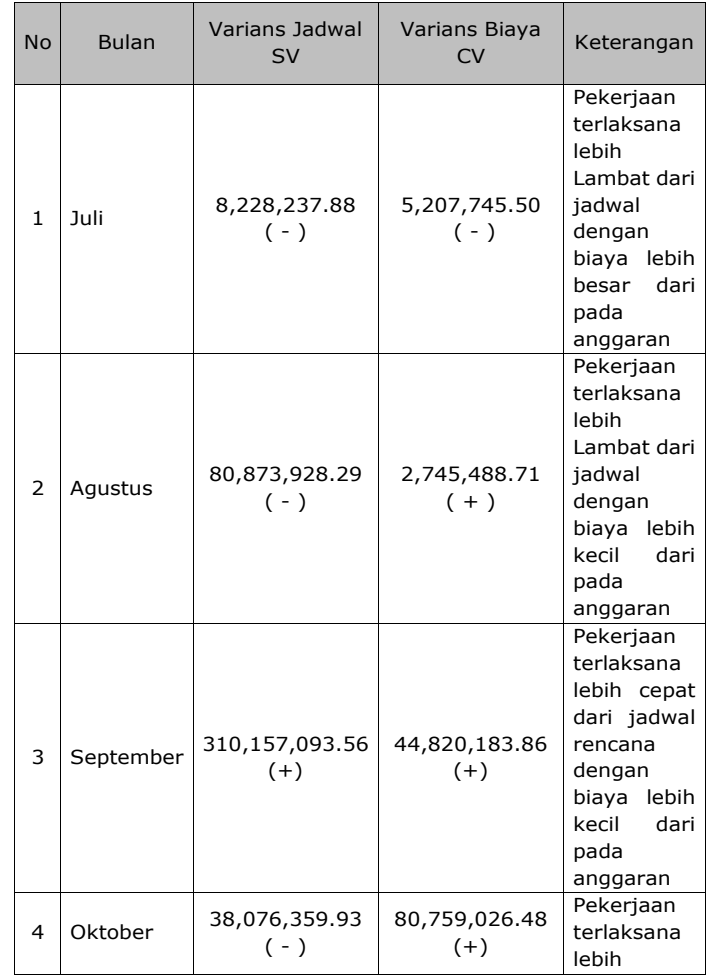

(Sumber : Hasil dari perhitungan nilai SV dan CV)

Perhitungan varians biaya (CV) sesuai tabel 1 , terlihat bahwa pekerjaan ini umumnya terlaksana dengan biaya kurang dari anggaran, ini terlihat dari nilai perhitungan CV didapatkan angka yang bernilai positif > 0 ( nol ) kecuali pada bulan Juli yang bernilai negatif.

8. Perkiraan biaya untuk pekerjaan tersisa (Estimate To Completion)

Yaitu untuk memberikan proyeksi mengenai akhir proyek atas dasar nilai angka yang diperoleh pada saat evaluasi. Rumus analisis perhitungan ETC tersebut adalah sebagai berikut :

$$
E T C=\frac{B A C-B C W P}{C P I}
$$

Sebagai contoh perhitungan ETC Bulan Agustus :

$\mathrm{ETC}=\frac{R p \cdot 3 \cdot 471 \cdot 830 \cdot 330,45-R p \cdot 60 \cdot 340 \cdot 411,143}{1.048}$

$$
=\text { Rp. 3.256.267.127,98 }
$$

Jadi, Perkiraan biaya untuk pekerjaan tersisa atau Estimate To Completion (ETC) adalah $=\mathrm{Rp}$. 3.256.267.127,98

Jadi, nilai dari perkiraan biaya untuk pekerjaan tersisa adalah terlihat pada tabel 8 Pada bulan Desember ETC $=0$, karena semua item pekerjaan telah selesai.

Tabel D.7 Hasil perhitungan pekerjaan tersisa atau ETC

\begin{tabular}{|c|l|l|r|r|r|}
\hline NO & BULAN & \multicolumn{1}{|c|}{$\begin{array}{c}\text { BAC } \\
\text { (Rp.) }\end{array}$} & $\begin{array}{c}\text { BCWP } \\
\text { (Rp.) }\end{array}$ & CPI & \multicolumn{1}{|c|}{$\begin{array}{c}\text { ETC } \\
\text { (Rp.) }\end{array}$} \\
\hline 1 & Juli & $.471 .830 .330,45$ & 0,000 & 0,000 & 0.000 \\
\hline 2 & Agustus & $.471 .830 .330,45$ & $60.340 .411,143$ & 1,048 & $3.256 .267 .127,98$ \\
\hline 3 & September & $.471 .830 .330,45$ & $1.093 .175 .216,145$ & 1,043 & $2.281 .130 .254,62$ \\
\hline 4 & Oktober & $.471 .830 .330,45$ & $1.700 .190 .031,125$ & 1,050 & $1.687 .487 .385,11$ \\
\hline 5 & Nopember & $.471 .830 .330,45$ & $3.146 .589 .265,093$ & 1,045 & $311.093 .079,01$ \\
\hline 6 & Desember & $.471 .830 .330,45$ & $3.471 .830 .330,450$ & 1,053 & 0,000 \\
\hline
\end{tabular}

(Sumber : Hasil analisa)

9. Perhitungan Estimate Actual Cost (EAC) EAC yaitu perkiraan biaya total proyek adalah jumlah pengeluaran sampai pada saat evaluasi atau ACWP ditambah perkiraan biaya untuk pekerjaan tersisa atau ETC. Untuk analisis perhitungan EAC adalah sebagai berikut :

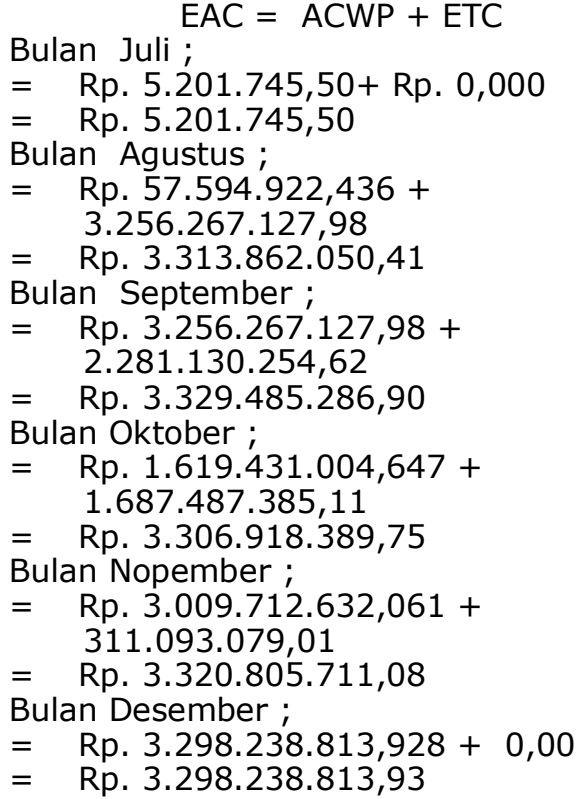

Tabel 9 Hasil perhitungan pekerjaan EAC

\begin{tabular}{|c|l|r|r|r|}
\hline NO & \multicolumn{1}{|c|}{ BULAN } & \multicolumn{1}{c|}{$\begin{array}{c}\text { ACWP } \\
\text { (Rp.) }\end{array}$} & \multicolumn{1}{c|}{$\begin{array}{c}\text { ETC } \\
\text { (Rp.) }\end{array}$} & \multicolumn{1}{c|}{$\begin{array}{c}\text { EAC } \\
\text { (Rp.) }\end{array}$} \\
\hline 1 & Juli & $5.201 .745,50$ & 0,000 & $5.207 .745,50$ \\
\hline 2 & Agustus & $57.594 .922,436$ & $3.256 .267 .127,98$ & $3.313 .862 .050,41$ \\
\hline 3 & September & $1.048 .355 .032,283$ & $2.281 .130 .254,62$ & $3.329 .485 .286,90$ \\
\hline 4 & Oktober & $1.619 .431 .004,647$ & $1.687 .487 .385,11$ & $3.306 .918 .389,75$ \\
\hline 5 & Nopember & $3.009 .712 .632,061$ & $311.093 .079,01$ & $3.320 .805 .711,08$ \\
\hline 6 & Desember & $3.298 .238 .813,928$ & 0,000 & $3.298 .238 .813,93$ \\
\hline
\end{tabular}

(Sumber : Hasil analisa)

Pada minggu ketiga bulan Desember maka semua pekerjaan telah selesai $100 \%$ sehingga nilai ETC adalah 0 (nol) dan anggaran biaya yang tersisa tidak ada lagi. Maka untuk nilai EAC pada akhir laporan bulan Desember adalah komulatif nilai ACWP dari bulan Juli sampai Desember. Adapun item pekerjaan pada awal Desember ini adalah demobilisasi dan selanjutnya dilakukan penyerahan pertama yaitu $\mathrm{PHO}$ serta FHO masa pemeliharaan selama 180 hari kalender. 


\section{PENUTUP}

Pada penelitian ini dapat disimpulkan sebagai berikut :

1. Pada hasil akhir dari analisa penerapan metode Konsep Nilai Hasil (Earned Value Concept) PT. Riau Maju Cemerlang mengalami keuntungan biaya nilai brutonya kurang lebih Rp.173.591.516,52 atau 5,00 \% dari total harga konstruksi tanpa nilai PPn.

2. Perencanaan awal waktu pelaksanaan pekerjaan proyek dimulai 26 Juli 2012 dan waktu perencanaan semula berakhir 17 Desember 2012 (145 HK) ternyata menjadi 27 Desember 2012 (155 HK). Keterlambatan 10 Hari Kalender ini disebabkan terlambatnya pelaksanaan pekerjaan Timbunan Pilihan untuk Bahu Jalan.

3. Penerapan metode Konsep Nilai Hasil terhadap proyek dapat mengetahui nilai biaya proyek tersisa pada bulan Agustus Rp.3.256.267.127,98; September Rp.2.281.130.254,62; Oktober Rp. 1.687.487.385,11; Nopember Rp. $311.093 .079,01$.

Setelah mengamati kinerja proyek ini, penulis memberikan saran sebagai berikut.

1. Pada penyusunan Time Schedule sebaiknya benar-benar efisien. Dapat membuat Time Schedule pekerjaan proyek dalam 3 (tiga) perencanaan yaitu :

a. Time Schedule waktu tercepat

b. Time Schedule waktu normal

c. Time Schedule waktu terlambat

2. Dan juga dalam penyusunan Rancangan Anggaran Biaya (RAB) sebaiknya dibuat dalam 3 (tiga) perencanaan yaitu :

a. RAB dengan Time Schedule waktu tercepat

b. RAB dengan Time Schedule waktu normal

c. RAB dengan Time Schedule waktu terlambat

3. Penerapan Konsep Nilai hasil ini sebaiknya juga diterapkan pada penelitian proyek yang beberapa item pekerjaan di-sub-kan atau diborongkan kepada fihak ketiga. Tentu nantinya akan ada perbedaan pada biaya dan waktu penlaksanaan proyek.

\section{DAFTAR PUSTAKA}

[1] Afridel, 2012, Penerapan Metode Konsep Nilai Hasil (Earned Value Concept) Terhadap Proyek Peningkatan Jalan Aspal 1, 00 km Ruas Jalan Sumber Jaya - Kuantan Sako. (Tugas Akhir), Teluk Kuantan, Program Studi S1 Teknik Sipil, Sekolah Tinggi Teknologi Unggulan Swarnadwipa.
[2] Departemen Pekerjaan Umum, 1987, Petunjuk Perencanaan Tebal Perkerasan Lentur Jalan Raya dengan Metode Analisa Komponen, SKBI 2.3.26. 1987, UDC. 625-78 (02) Yayasan Badan Penerbit Pekerjaan Umum, Jakarta.

[3] Dinas Bina Marga dan Sumber Daya Air, 2012, Dokumen Kontrak paket Proyek Peningkatan Jalan Sambung - Kebun Lado (Aspal 2,00 $\mathrm{Km}$ ) pada Pembangunan Jalan Kabupaten Kuantan Singingi,Teluk Kuantan. http://www.kuansing.com/doc/

[4] Nurhayati, 2010, Manajemen Proyek, Graha Ilmu, Yogyakarta.

[5] Renoldikosasi, 2009, Penerapan Konsep Nilai Hasil (Earned Value Concept) Studi Kasus Proyek Pembangunan Jalan Simpang Haru - Batas Kota Padang (Tahap II), Skripsi, Jur. Tek.Sipil Universitas Bung Hatta, Padang

[6] Rukmayadi Dede, 2010, Manajemen Proyek, Pusat Pengembangan Bahan Ajar-UMB, Bandung

[7] Prodi Teknik Sipil FT UNIKS, 2015, Penulisan Tugas Akhir dan Kerja Praktek, Teluk Kuantan.

[8] Soeharto Iman, 1995, Manajemen Proyek dari konseptual sampai operasional, Penerbit Erlangga.

[9] Sukirman, S, 1999, Perkerasan Lentur Jalan Raya, Cetakan Kelima, Nova Bandung. 
Tabel 10 Hasil Perhitungan Pekerjaan dengan Konsep Nilai Hasil

\begin{tabular}{|c|c|c|c|c|c|c|c|c|c|c|}
\hline $\begin{array}{c}\text { BULAN } \\
2012 \\
\end{array}$ & BCWS & BCWP & ACWP & sv & CV & SPI & CPI & ETC & BAC & EAC \\
\hline 1 & 2 & 3 & 4 & 5 & 6 & 7 & 8 & 9 & 10 & 11 \\
\hline JULI & $8,228,237.883$ & - & $5,207,745.50$ & $-8,228,237.88$ & $-5,207,745.50$ & 0.000 & 0.000 & 0.00 & $3,471,830,330.45$ & $5,207,745.50$ \\
\hline AGUSTUS & $141,214,339.431$ & $60,340,411.143$ & $57,594,922.436$ & $-80,873,928.29$ & $2,745,488.71$ & 0.427 & 1.048 & $3,256,267,127.98$ & $3,471,830,330.45$ & $3,313,862,050.41$ \\
\hline SEPTEMBER & $783,018,122.584$ & $1,093,175,216.145$ & $1,048,355,032.283$ & $310,157,093.56$ & $44,820,183.86$ & 1.396 & 1.043 & $2,281,130,254.62$ & $3,471,830,330.45$ & $3,329,485,286.90$ \\
\hline OKTOBER & $1,738,266,391.060$ & $1,700,190,031.125$ & $1,619,431,004.647$ & $-38,076,359.93$ & $80,759,026.48$ & 0.978 & 1.050 & $1,687,487,385.11$ & $3,471,830,330.45$ & $3,306,918,389.75$ \\
\hline NOVEMBER & $3,340,912,794.060$ & $3,146,589,265.093$ & $3,009,712,632.061$ & $194,323,528.97$ & $136,876,633.03$ & 0.942 & 1.045 & $311,093,079.01$ & $3,471,830,330.45$ & $3,320,805,711.08$ \\
\hline DESEMBER & $3,471,830,330.450$ & $3,471,830,330.450$ & $3,298,238,813.928$ & 0.00 & $173,591,516.52$ & 1.000 & 1.053 & 0.00 & $3,471,830,330.45$ & $3,298,238,813.93$ \\
\hline
\end{tabular}

KETERANGAN :

\author{
BCWS $=\%$ Renc $\times$ Total Anggaran \\ $\mathrm{BCWP}=\%$ Real $\times$ Total Anggrn \\ ACWP $=$ Data Keuangn Kontraktor \\ $\mathrm{SV}=\mathrm{BCWP}-\mathrm{BCWS}$ \\ $C V=B C W P-A C W P$ \\ $\mathrm{SPI}=\mathrm{BCWP} / \mathrm{BCWS}$ \\ $\mathrm{CPI}=\mathrm{BCWP} / \mathrm{ACWP}$ \\ $\mathrm{ETC}=(\mathrm{BAC}-\mathrm{BCWP}) / \mathrm{CPI}$ \\ $E A C=A C W P+E T C$ \\ $B A C=$ RAB Tanpa PPn
}

